Dicle University Journal of Engineering (DUJE)

web: http://dergipark.gov.tr/dumf

Araștırma Makalesi / Research Article

\title{
Bingöl ve Elazığ İlleri Özelinde 2007 ve 2018 Türk Deprem Yönetmeliklerine Göre İvme Spektrumlarının Değişiminin İncelenmesi
}

\section{Investigation of the Change of Acceleration Spectra in Bingöl and Elazığ Provinces According to 2007 and 2018 Turkish Earthquake Codes}

\author{
Ömer Faruk Nemutlu1, Bilal Balun², Ahmet Benli ${ }^{3}$, Ali Sarı ${ }^{4}$ \\ ${ }^{1}$ Bingöl Üniversitesi, Enerji, Çevre ve Doğal Afet Çalışmaları Uygulama ve Araştırma Merkezi, İnşaat Mühendisliği Bölümü, Bingöl, Türkiye, \\ ofnemutlu@bingol.edu.tr \\ ${ }^{2}$ Bingöl Üniversitesi, Enerji, Çevre ve Doğal Afet Çalışmaları Uygulama ve Araştırma Merkezi, Mimarlık Bölümü, Bingöl, Türkiye, \\ bbalun@bingol.edu.tr \\ ${ }^{3}$ Bingöl Üniversitesi, Enerji, Çevre ve Doğal Afet Çalışmaları Uygulama ve Araştırma Merkezi, İnşaat Mühendisliği Bölümü, Bingöl, Türkiye, \\ abenli@bingol.edu.tr \\ 4 İnşaat Fakültesi, İstanbul Teknik Üniversitesi, İstanbul, Türkiye, asari@itu.edu.tr
}

\begin{tabular}{l} 
MAKALE BİLGILERİ \\
\hline Makale geçmişi: \\
Geliş: 12 Mart 2020 \\
Düzeltme: 27 Nisan 2020 \\
Kabul: 20 Mayıs 2020 \\
\hline Anahtar kelimeler: \\
Deprem Yönetmelikleri, İvme \\
Spektrumları, Sismik Tasarım, \\
TBDY 2018, DBYBHY 2007
\end{tabular}

Doi: $10.24012 /$ dumf. 703138

\begin{abstract}
ÖZET
Günümüzde inşaat alanında meydana gelen teknolojik gelişmeleri uygulamada aktif ve doğru bir şekilde kullanabilmek için ülkemizde 2007 yılında yürürlüğe giren ‘Deprem Bölgelerinde Yapılacak Binalar Hakkında Yönetmelik' yerini 1 Ocak 2019 tarihi itibariyle 'Türkiye Bina Deprem Yönetmeliği'ne bırakmıștır. Türkiye sınırları içerisinde yoğun olarak aktif tektonik faylar bulunmasından dolayı depreme dayanıklı yapı tasarımı büyük önem arz etmektedir. Depreme karșı tasarımda yapılara etkiyecek deprem yüklerinin tespitinde tasarım ivme spektrumları kullanılmaktadır. Bu çalışmanın amaç, 2007 Türk deprem yönetmeliğinden 2018 Türk deprem yönetmeliğine geçilirken meydana gelen deprem hesap esaslarındaki değişimin incelenmesidir. Bu çalışmada 2007 Türk deprem yönetmeliğine göre iki farklı deprem bölgesinde yer alan Bingöl ve Elazığ il sehir merkezlerinin, 2007 ve 2018 Türk deprem yönetmeliklerine göre ivme spektrumları karșılaștırılmıștır. Calıșma kapsamında ele alınan bölgeler için farklı deprem yer hareket düzeylerine göre ivme spektrumlarının, köşe periyotlarının, koordinata dayalı spektrum katsayılarının farklı zemin sınıflarına göre değişimi irdelenmiştir. 2007 deprem yönetmeliği ile 2018 deprem yönetmeliği karşılaştırıldığında, 2007 deprem yönetmeliğinde ivme spektrumları bölgesel olarak farklılık göstermez iken, 2018 yönetmeliğinde Afet ve Acil Durum Başkanlı̆̆ı'nın oluşturduğu Türkiye Deprem Tehlike Haritalarından alınan ivme parametrelerinin koordinat odaklı değișimi bölgesel bir farklılık göstermesinden kaynaklı olarak ivme spektrumlarında farklılıklar meydana geldiği görülmüştür. Deprem tasarım esaslarında koordinata bağlı çalışan 2018 Türk deprem yönetmeliğinde ivme spektrumları kullanılacağı konumuna göre değişiklik göstermektedir. 2007 Türk deprem yönetmeliğinde ise ivme spektrumları konuma göre değişiklik göstermemektedir. Bu nedenle deprem tasarım esasları açısından, 2018 Türk deprem yönetmeliğindeki ivme değerlerinin, 2007 Türk deprem yönetmeliğindeki sabit ivme değerlerine kıyasla ekonomik ve emniyetli bir durum gösterdiği söylenebilir.
\end{abstract}

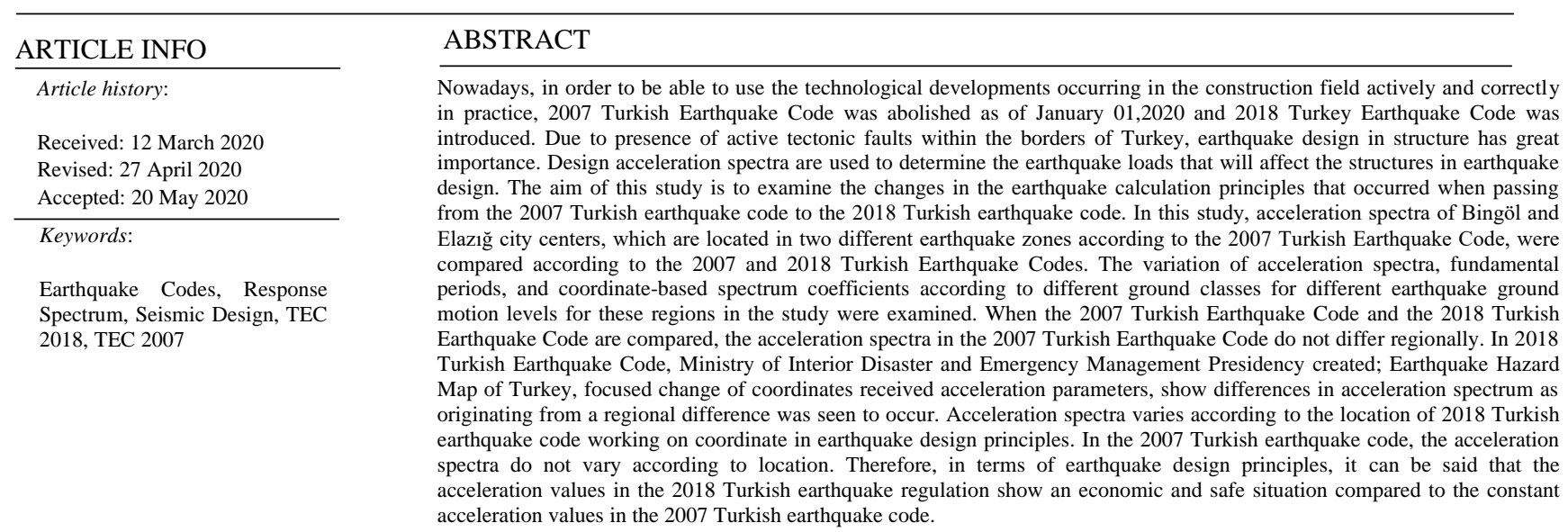

* Sorumlu yazar / Correspondence

Ahmet BENLI

$\triangle$ abenli@bingol.edu.tr 


\section{Giriș}

Türkiye, sınırları içerisinde bulunan aktif faylar nedeniyle tarih boyunca önemli depremlere maruz kalmıştır. Bu faylardan yaklaşık 1000 km uzunluğunda olan Kuzey Anadolu Fay hattı ve yaklaşık $400 \mathrm{~km}$ uzunluğunda olan Doğu Anadolu Fay hattı ülkeyi doğu-batı ve güneydoğu-kuzeydoğu ekseninde çevrelemektedir [1]. Şekil 1'de Türkiye'deki önemli fayları ve Türkiye sınırlarındaki plakları gösteren harita verilmiştir [2]. $\mathrm{Bu}$ faylar üzerinde önemli aktif tektonik hareketler tarih boyunca ülkemizde önemli depremler meydana getirmiştir. $\mathrm{Bu}$ depremler önemli can ve mal kayıplarına neden olmuştur. Örneğin 1939 y1lında meydana gelen Erzincan 7.9 (Ms) depremi, 23.10.2011 yilında meydana gelen Van 7.2 (Ms) depremi, 22.05.1971 tarihinde meydana gelen 6.8 (Ms) Bingöl depremi ve 17.08.1999 tarihinde meydana gelen Gölcük (Kocaeli) 7.8 (Ms) depremi verilebilir [3].

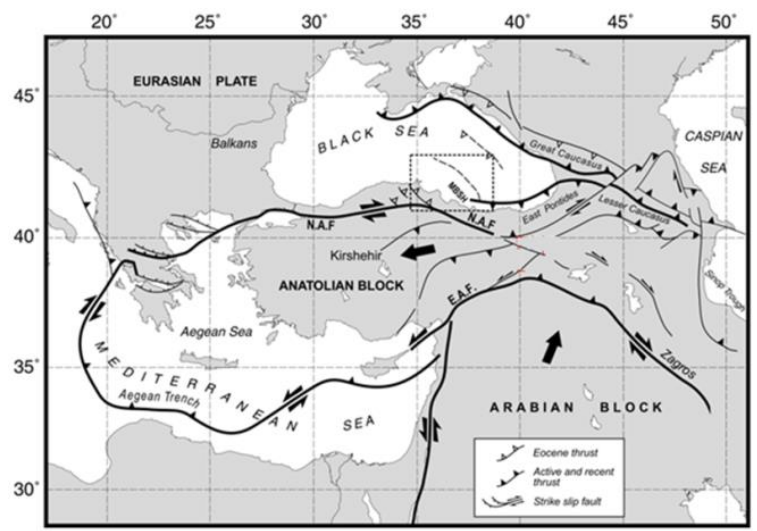

Şekil 1. Türkiye Fay Haritası [2]

$\mathrm{Bu}$ depremler sonucunda ülkemizde yapıların depreme dayanıklı şekilde tasarlanması her zaman önemli bir kriter olmuştur. Bu nedenle ülkemizde tarih boyunca çağın gereksinimlerini karşılayacak ve deprem hesapları yapılırken göz önüne alınacak minimum tasarım koşulları ve sınırlar deprem yönetmelikleriyle verilmiștir. 2016 y1lında taslak hali yayınlanan ve 18.03.2018 tarihli resmi gazetede yayınlanarak yürürlüğe giren 2018 Türkiye Bina Deprem
Yönetmeliği (TBDY)'ne kadar 1940'tan itibaren ülkemizde 10 adet deprem yönetmeliği yürürlüğe girmiştir [4-6]. Tablo 1'de bu yönetmelikler kronolojik sira ile verilmiştir. 1998 deprem yönetmeliğinden sonra 2007 Deprem Bölgelerinde Yapılacak Binalar Hakkında Yönetmelik (DBYBHY) hazırlanırken; çelik binalar için depreme dayanıklı yap1 tasarımı bölümünün detaylandirılmasi, mevcut binaların değerlendirilmesi ve güçlendirilmesi bölümünün eklenmesi, 1998 yönetmeliğinde yer alan ahşap ve kerpiç binaların depreme dayanıklı tasarımına ait bölümlerin kaldırılması gibi küçük çaplı değişiklikler haricinde büyük çaplı bir değişiklik yapılmamıştır. Bu nedenle 1998 yönetmeliğinden itibaren ülkemizdeki deprem yönetmeliği yaklaşık 20 y1l gibi bir süre değişiklik görmeden kullanılmıştır [7]. $\mathrm{Bu}$ nedenle tamamen yeni bir yönetmelik olarak hazırlanan Türkiye Bina Deprem Yönetmeliği bir ihtiyaç olarak ortaya çıkmıştır [8]. 2018 TBDY ülkemizde 1 Ocak 2019 tarihinden itibaren kullanımı zorunlu hale gelerek Deprem Bölgelerinde Yapılacak Binalar Hakkında Yönetmelik 2007'nin yerini almıştır. Ayrıca Afet ve Acil Durum Başkanlığı'nın (AFAD) yeni yönetmelik çalışmaları ile paralel olarak yürüttüğü Türkiye Deprem Tehlike Haritaları da yeni yönetmelikle birlikte kullanıma sunulmuştur [9]. İnteraktif web uygulaması üzerinden erişilebilen haritaya e-devlet bilgileri kullanılarak girilmektedir. 2007 DBYBHY'de dikkate alınan Türkiye Deprem Bölgeleri haritası yerine geçen tehlike haritaları, bölge haritalarında olduğu gibi sabit katsayılar ile çalışmak yerine kısa periyot ve uzun periyot için ayrı ayrı olmak üzere koordinata dayalı ivme parametreleriyle hesap yapmaya izin vermektedir. 2007 deprem yönetmeliğinde kullanılan Deprem Bölgeleri Haritası ve kullanımına geçilen 2018 deprem yönetmeliğinde kullanılan Deprem Tehlike Haritaları sırasıyla Şekil 2 ve Şekil 3'te verilmiştir $\quad[6,6,9, \quad 10]$. 
Tablo 1. Türkiye'de tarih boyunca yürürlüğe girmiş olan yönetmelikler [4]

\begin{tabular}{llcc}
\hline Y11 & \multicolumn{1}{c}{ Tam İsmi } & Kısaltması \\
\hline 1940 & $\begin{array}{l}\text { Zelzele Mıntıkalarında Yapılacak İnşaata ait İtalyan } \\
\text { Talimatnamesi }\end{array}$ & Yapı \\
1944 & $\begin{array}{l}\text { Zelzele Mıntıkaları Muvakkat Yapı Talimatnamesi } \\
1949\end{array}$ & Türkiye Yersarsıntısı Bölgeleri Yapı Yönetmeliği \\
1953 & Yersarsıntısı Bölgelerinde Yapılacak Yapılar Hakkında Yönetmelik & - \\
1962 & Afet Bölgelerinde Yapılacak Binalar Hakkında Yönetmelik & ABYBHY \\
1968 & Afet Bölgelerinde Yapılacak Binalar Hakkında Yönetmelik & ABYBHY \\
1975 & Afet Bölgelerinde Yapılacak Binalar Hakkında Yönetmelik & ABYBHY \\
1998 & Afet Bölgelerinde Yapılacak Binalar Hakkında Yönetmelik & ABYBHY \\
2007 & Deprem Bölgelerinde Yapılacak Binalar Hakkında Yönetmelik & DBYBHY \\
2018 & Türkiye Bina Deprem Yönetmeliği & TBDY \\
\hline
\end{tabular}

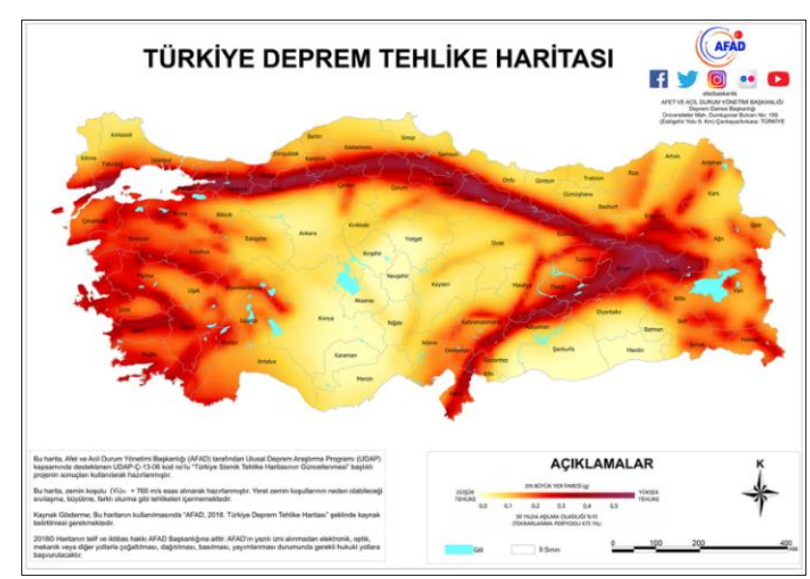

Şekil 2. Türkiye Deprem Tehlike Haritası [6]

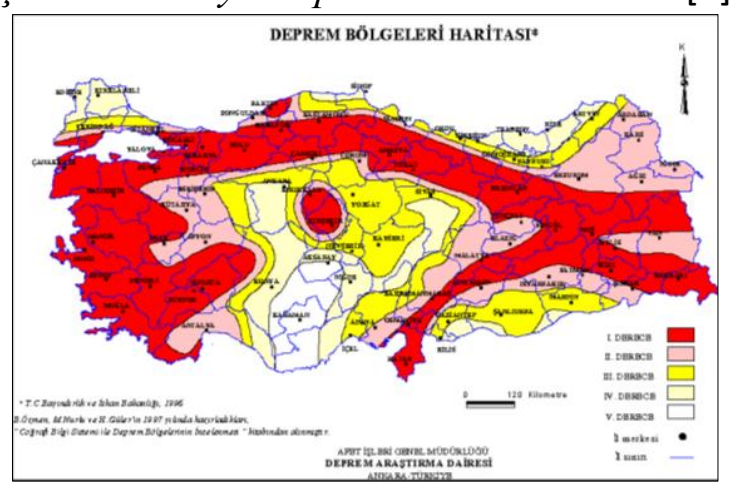

Şekil 3. Türkiye Deprem Bölgeleri Haritasl[10]
Deprem yönetmeliklerinde verilen tasarım spektrumları, yapıların depreme karşı tasarımında ve yapılara etkiyen deprem yüklerini belirlemede kullanılır. Tepki spektrumları, tek serbestlik dereceli sistemlerde belirli bir sönüm oranı için elde edilen en büyük yer değiştirme, ivme veya hız değerlerinin periyot veya frekansa karşı değişimini göstermektedir. [11-13]. Bu çalışma kapsamında 2007 ve 2018 Türk deprem yönetmeliklerindeki tasarım ivme spektrumları, 2007 deprem yönetmeliğine göre 1. derece deprem bölgesi olarak tanımlanan Bingöl ili şehir merkezi ve 2 . Derece deprem bölgesi olarak tanımlanan Elazığ ili şehir merkezi için oluşturularak, 2007 ve 2018 deprem yönetmeliklerinin köşe periyotları ve ivme değerleri arasındaki farklar ile farklı zemin sinıflarına göre tasarım spektrumlarında meydana gelen değişiklikler irdelenmiştir.

\section{İvme Spektrumu Kavramı}

İvme spektrumu, deprem etkisine maruz kalan tek serbestlik dereceli bir sistemin davranışının (hız, ivme ve yer değiştirme) maksimumunu, serbest titreşim periyoduna 
bağlı olarak gösteren eğridir [14]. Tasarım spektrumları ise yeni yapıların tasarımında kullanılacak deprem yükünü belirlerken kullanılır. Bir tasarım spektrumu hazırlanırken dikkate alınan bölgede geçmişte ortaya çıkmış depremler göz önüne alınarak gelecekte ortaya çıkması olası depremlerin belirlenmesi amaçlanır. Yapıların deprem etkisi altındaki tasarımını tanımlarken deprem spektrumları kullanılır. İvme spektrum eğrisi, göz önüne alınan bir deprem yer hareketinin tek serbestlik dereceli sisteme uygulanmasıyla elde edilen mutlak ivmelerin en büyük değerlerinin toplanmasıyla elde edilir. İvme spektrumları tasarım spektrumlarına dönüştürülerek yapıya etki etkimesi beklenen kuvvetler yanında yer değiştirmeler de bulunabilir [14]. Genelde tasarım spektrumları bir bölgede kaydedilmiş çok sayıda deprem için çizilmiş spektrumların istatistik yöntemlerle değerlendirilmesi sonucu elde edilirler. Tasarım spektrumlarının oluşturulması ile ilgili maksimum yer hareketi ivmesi yöntemi, Newmark-Hall yöntemi ve Housner yaklaşımı gibi yaklaşımlar literatürde mevcuttur [15-17]. Tasarım bazlı yer hareketlerinin tanımlanmasında kullanılan tasarım spektrumları genel olarak deprem tehlikesi bölge haritalarından belirlenecek deprem parametrelerine yani en büyük yer ivmesine bağımlı tasarım spektrumları, deprem tehlikesi haritalarından belirlenecek deprem parametrelerine $(0.2 \mathrm{~s}$ ve $1 \mathrm{~s}$ periyotlarındaki spektral ivmeler) bağımlı tasarım spektrumları ve sahaya özel tehlike analizleri olarak ayrılmaktadır. Daha önceden yürürlükte olan 2007 DBYBHY'de en büyük yer ivmesine bağıml tasarım spektrumları kullanılırken, 2018 TBDY, ASCE 7-16 ve IBC 2018 gibi yönetmeliklerde $0.2 \mathrm{~s}$ ve $1 \mathrm{~s}$ periyotlarındaki spektral ivmelere bağıml tasarım ivme spektrumları kullanılmaktadır [18-26].

\section{7 ve 2018 Deprem Yönetmeliklerinde İvme Spektrumları}

2007 DBYBHY'de spektrum katsayıs1, $\mathrm{S}(\mathrm{T})$, yerel zemin koşullarına (TA ve TB) ve bina doğal periyoduna $(\mathrm{T})$ göre değişmektedir. $\mathrm{Bu}$ yönetmelikte TA ve TB katsayıları yerel zemin sınıflarına göre değişmekle birlikte sabit katsayılar halinde verilmiştir.

$$
\begin{gathered}
S(T)=1+1.5 \frac{T}{T_{A}} \quad 0 \leq T \leq T_{A} \\
S(T)=2.5 \quad T_{A} \leq T \leq T_{B} \\
S(T)=2.5\left(\frac{T_{B}}{T}\right)^{0.8} \quad T_{B}<T
\end{gathered}
$$

2018 TBDY'de elastik tasarım spektral ivmesi, $\mathrm{S}_{\mathrm{ae}}(\mathrm{T})$, yer çekimi ivmesi cinsinden doğal titreşim periyodu ile $S_{D S}$ ve $S^{D 1}$ parametrelerine göre hesaplanabilmektedir. Burada dikkat edilmesi gereken koşullardan biri olarak; köşe periyotları (TA ve TB) sabit katsay1lar olarak verilmeyip $S_{D S}$ ve $S_{D 1}$ parametrelerine göre değişiklik göstermektedir.

$$
\begin{gathered}
S_{a e}(T)=\left(0.4+0.6 \frac{T}{T_{A}}\right) S_{D S} \quad 0 \leq T \leq T_{A} \\
S_{a e}(T)=S_{D S} \quad T_{A} \leq T \leq T_{B} \\
S_{a e}(T)=\frac{S_{D 1}}{T} \quad T_{B} \leq T \leq T_{L} \\
S_{a e}(T)=\frac{S_{D 1} T_{L}}{T^{2}} \\
T_{A}=0.2 \frac{S_{D 1}}{S_{D S}}
\end{gathered}
$$

2007 DBYBHY ve 2018 TBDY'deki elastik tasarım ivme spektrumları sırasıyla Şekil 4 ve 5 'te verilmiştir. 2018 deprem yönetmeliğinde 2007'den farklı olarak düşey elastik tasarım ivme spektrumu tanımlanmıştır. Düşey deprem etkisi; DTS=1, DTS=1a, DTS=2 ve DTS $=2$ a olarak sınıflandırılan ve açıklıklarının yataydaki izdüşümü $20 \mathrm{~m}$ veya daha fazla olan kirişleri içeren binalar, açıklıklarının yataydaki izdüşümü $5 \mathrm{~m}$ veya daha fazla olan konsolları içeren binalar, kirişlere oturan kolonları içeren binalar ve kolonları düşeye göre eğimli olan binalarda dikkate alınır. 


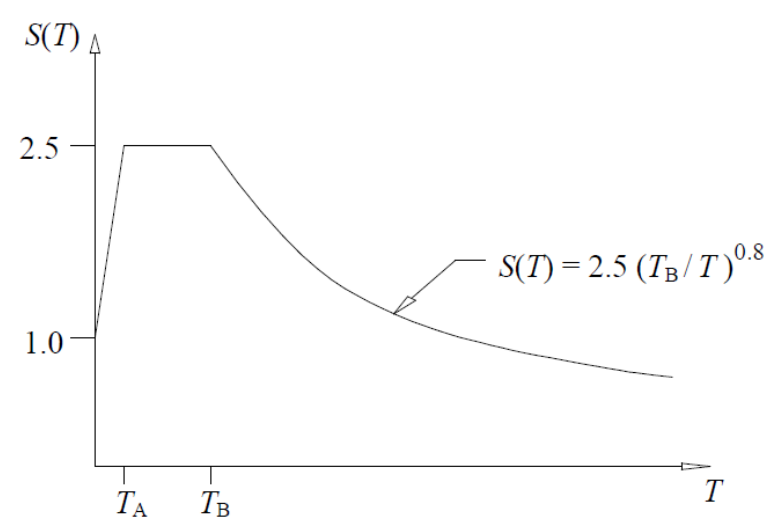

Şekil 4. 2007 DBYBHY elastik tasarım ivme spektrumu [10]

Şekil 4'te görüldüğü üzere 2007 DBYBHY deprem yönetmeliğinde yapıya etki ettirilecek maksimum ivme değeri spektrumda $2.5 \mathrm{~g}$ zirve değeri ile sınırlandırılmıştır. Şekil 5 'teki TBDY 2018 yatay elastik tasarım ivme spektrumunda ise maksimum ivme değeri Türkiye deprem tehlike haritalarından alınan parametrelerden deprem etkisini ifade eden $S_{D S}$ parametresiyle değişken zirve değerler almaktadır.

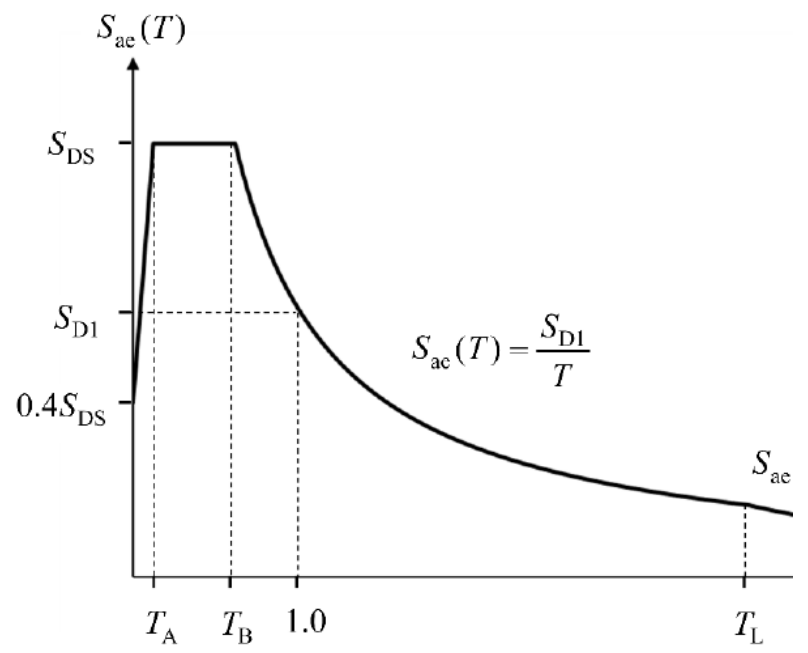

Şekil 5. 2018 TBDY yatay elastik tasarım ivme spektrumu[6]

\section{Çalışma ve Bulgular}

Bu çalışmada 2007 DBYBHY ve 2018 TBDY'deki ivme spektrumları Bingöl ve Elazığ ili için farklı zemin sınıfları göz önüne alınarak karşılaştırılmıştır 2007 deprem yönetmeliğindeki deprem bölgeleri kavramına göre, 38.8855 enlem ve 40.5101 boylamda bulunan Bingöl şehir merkezi 1. derece deprem bölgesi olarak, 38.6705 enlem ve 39.2373 boylamda bulunan Elazı ̆ şehir merkezi 2. derece deprem bölgesi olarak kabul edilmiştir. 2007 deprem yönetmeliğine göre oluşturulan ivme spektrumları 475 yıl geri dönüş periyoduna sahip standart deprem yer hareketi düzeyine göre oluşturulmuştur. 2018 deprem yönetmeliğine göre oluşturulan ivme spektrumlarında ise Afet ve Acil Durum Yönetim Başkanlığının (AFAD) oluşturduğu interaktif web uygulaması üzerinden DD-1, DD-2, DD-3 ve DD-4 olmak üzere 4 farkl1 deprem yer hareket düzeyi dikkate alınmıştır. Deprem yer hareket düzeyleri 2018 deprem yönetmeliğinde tanımlanmıştır [6]. Göz önüne alınan en büyük deprem yer hareketi olarak ta adlandırılan DD-1 deprem yer hareket düzeyi, spektral büyüklüklerin 50 yılda aşılma olasılığ $\% 2$ olan ve tekrarlanma periyodunun 2475 yıl olduğu çok seyrek deprem yer hareketlerini belirtmektedir. Standart tasarım deprem yer hareketi olan DD-2 deprem yer hareket düzeyi, spektral büyüklüklerin 50 yılda aşılma olasılığı \%10 ve tekrarlanma periyodu 475 yıl olan çok sık depremleri tanımlamaktadır. DD-3 ve DD-4 deprem yer hareket düzeylerinin spektral büyüklüklerinin 50 yılda aşılma olasılıkları sirasıyla $\% 50$ ve \%68'dir. DD-3 deprem yer hareket düzeyinin tekrarlanma periyodu 72 y1l iken DD-4 deprem yer hareket düzeyinin 43 yıldır. DD-3 deprem yer hareket düzeyi genel olarak sik meydana gelen depremleri niteler. Servis deprem yer hareketi olarak DD-4 deprem yer hareket düzeyi kabul edilmektedir.

2018 TBDY'de DD-2 olarak tanımlanan standart deprem yer hareket düzeyi, 2007 DBYBHY'de göz önüne alınan standart deprem yer hareket düzeyi (50 yılda aşılma olasılığ $\% 10$ ve dönüş periyodu 475 yıl) ile eş değerdir. $\mathrm{Bu}$ nedenle oluşturulan grafiklerde 2007 DBYBHY'de tek ivme spektrumu 2018 TBDY'de ise 4 farklı ivme spektrumu eğrileri verilmiştir. Bingöl ili şehir merkezi için 2007 ve 2018 deprem yönetmelikleri ivme spektrumları Şekil 6, Şekil 7, Şekil 8, Şekil 9 ve Şekil 10'da verilmiştir. Elazığ ili Şehir merkezi için 2007 ve 2018 deprem yönetmelikleri ivme spektrumları ise Şekil 11, Şekil 12, Şekil 13, Şekil 14 ve Şekil 15'te gösterilmektedir. 

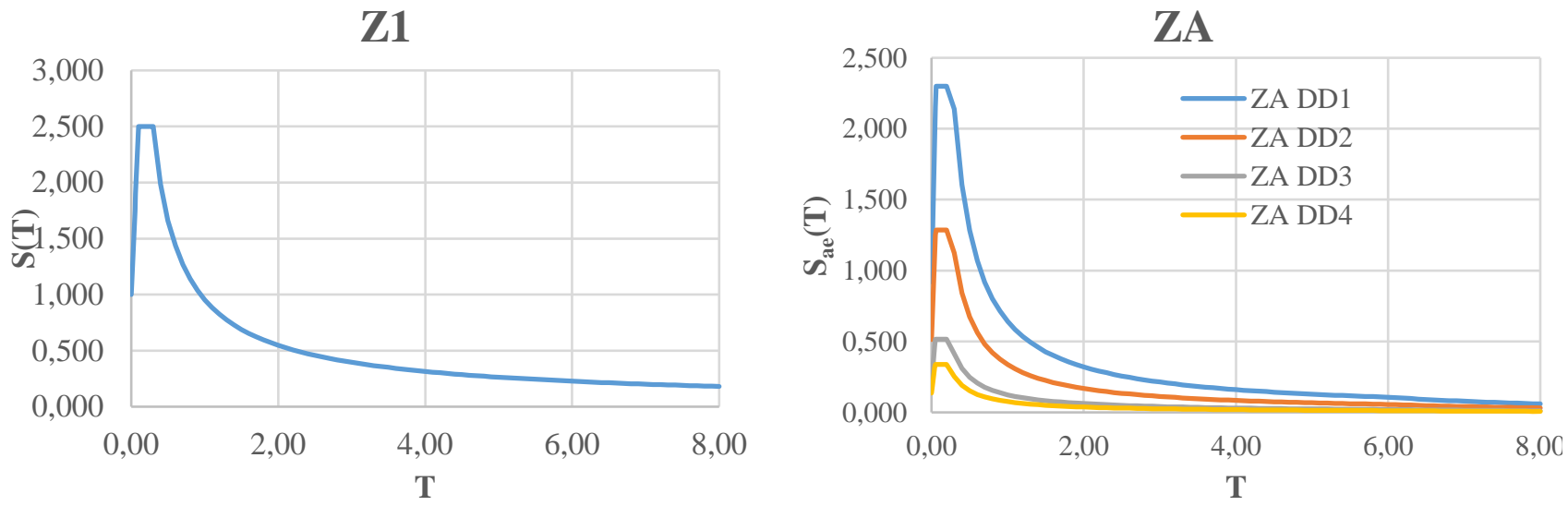

Şekil 6. Bingöl ili Z1-ZA ivme spektrumlart
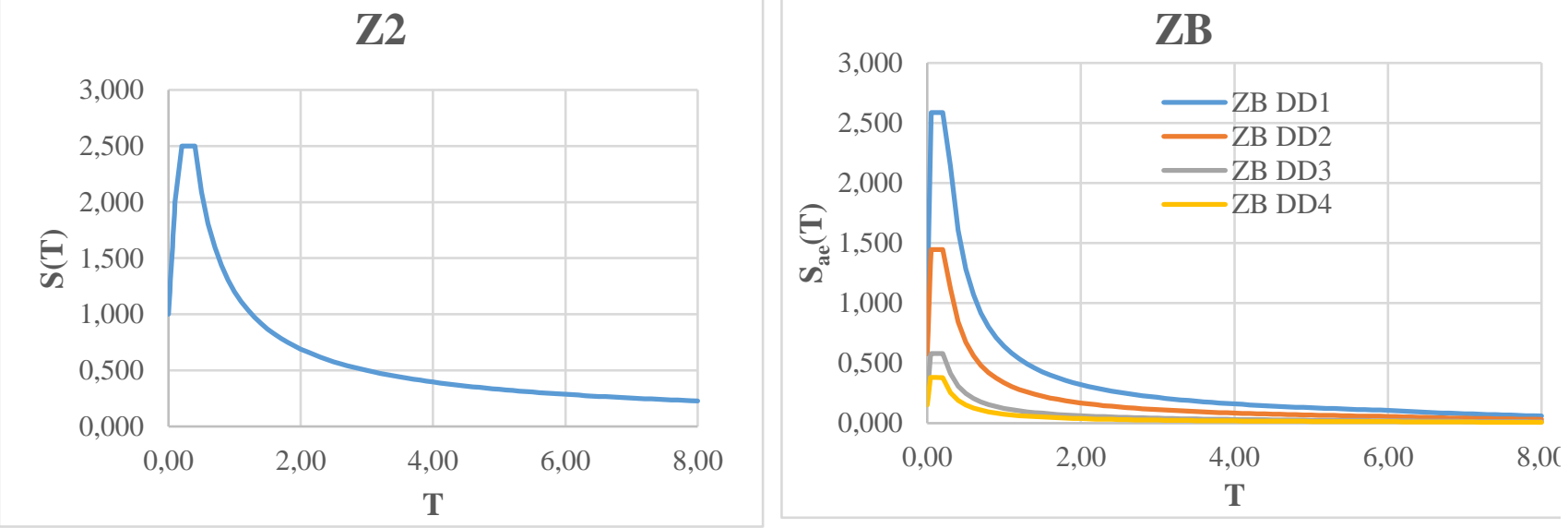

Şekil 7. Bingöl ili Z2- ZB ivme spektrumlart
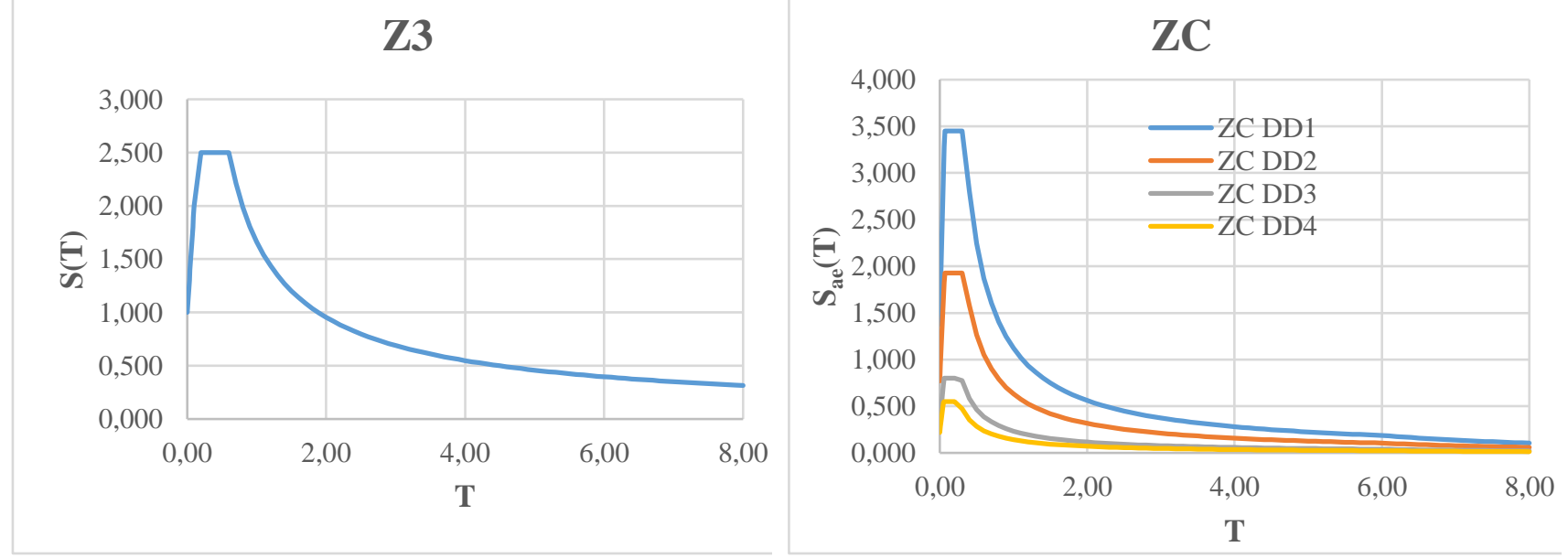

Şekil 8. Bingöl ili Z3- ZC ivme spektrumlart 

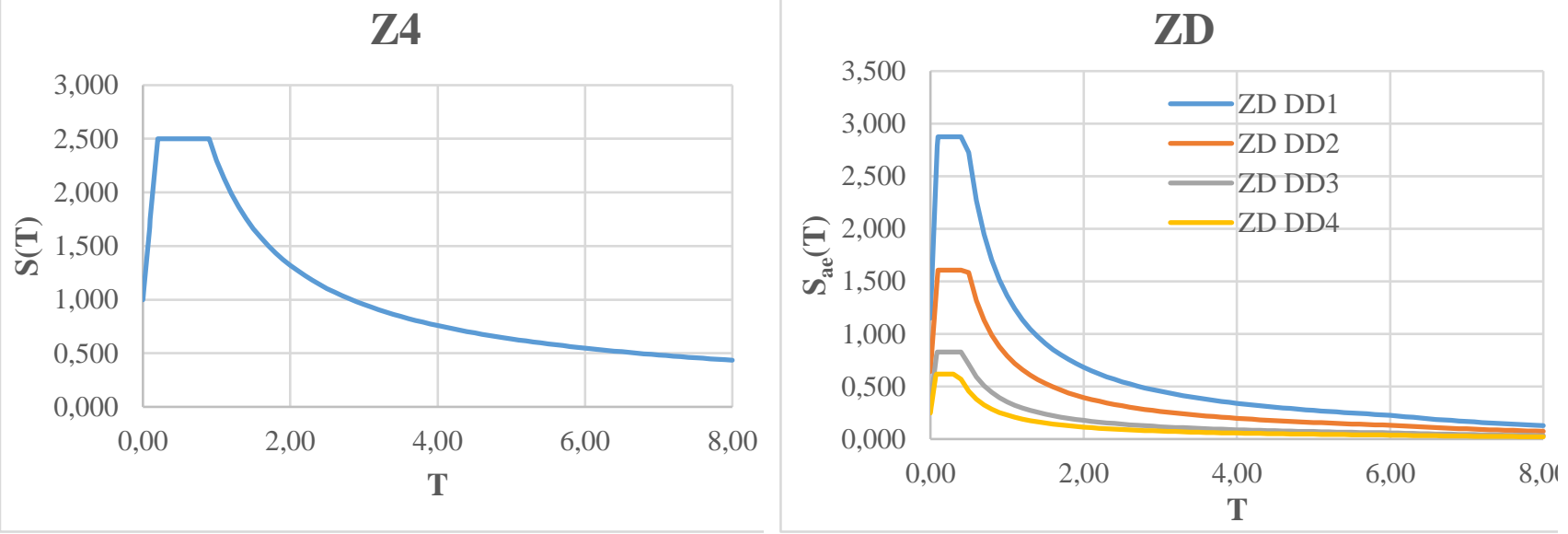

Şekil 9. Bingöl ili Z4- ZD ivme spektrumlart
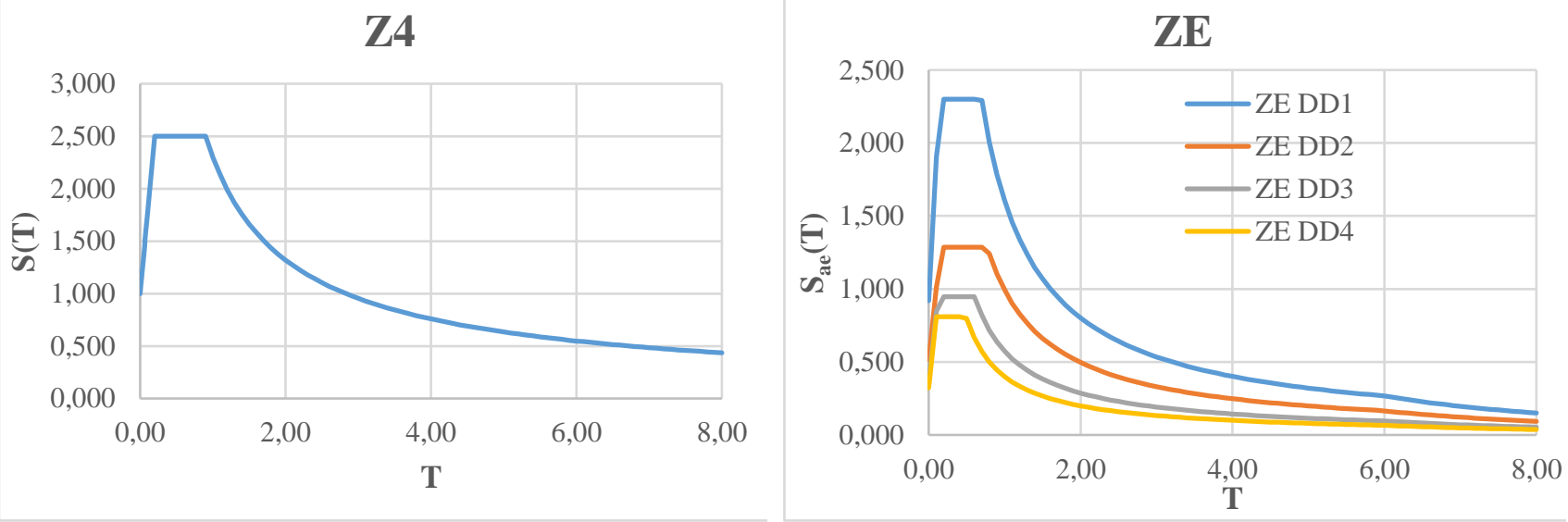

Şekil 10. Bingöl ili Z4- ZE ivme spektrumlarl
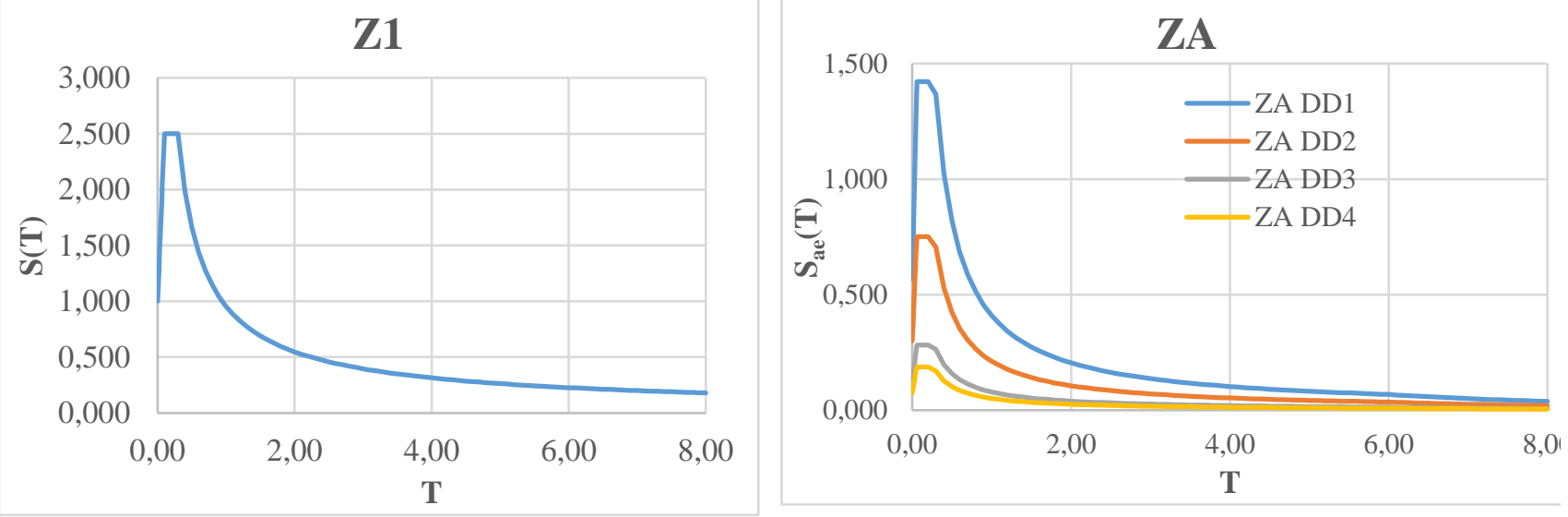

Şekil 11. Elazığ ili Z1-ZA ivme spektrumlart 

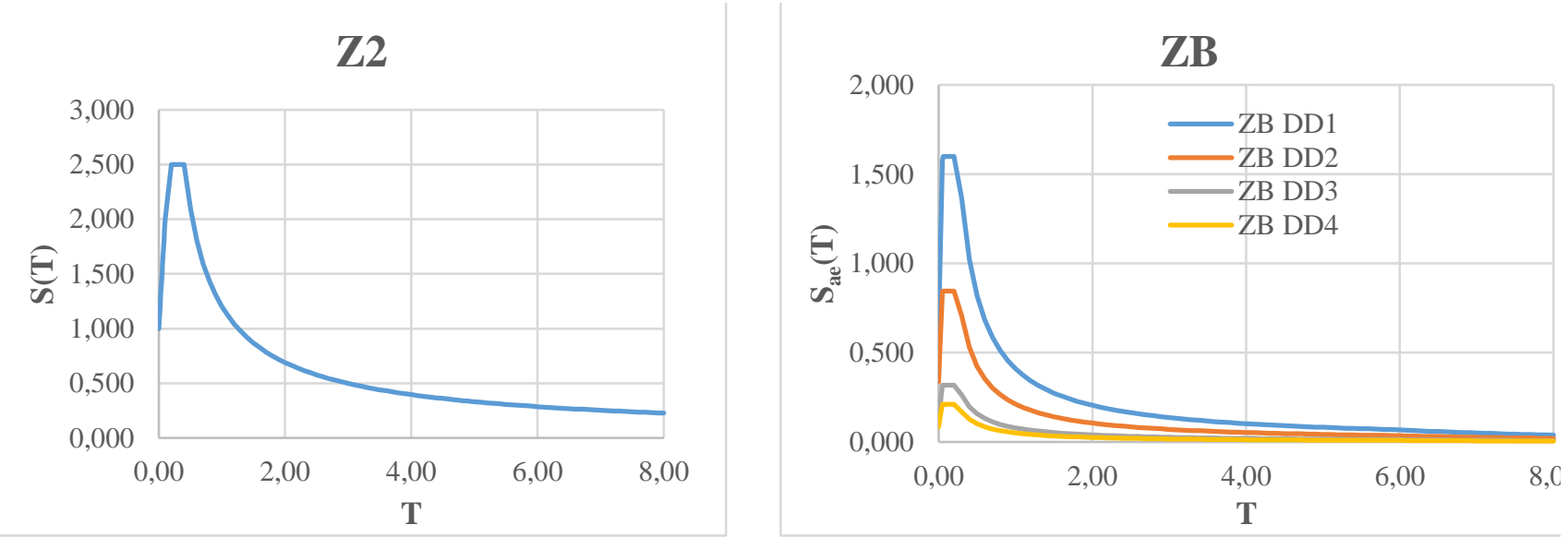

Şekil 12. Elazığ ili Z2- ZB ivme spektrumları
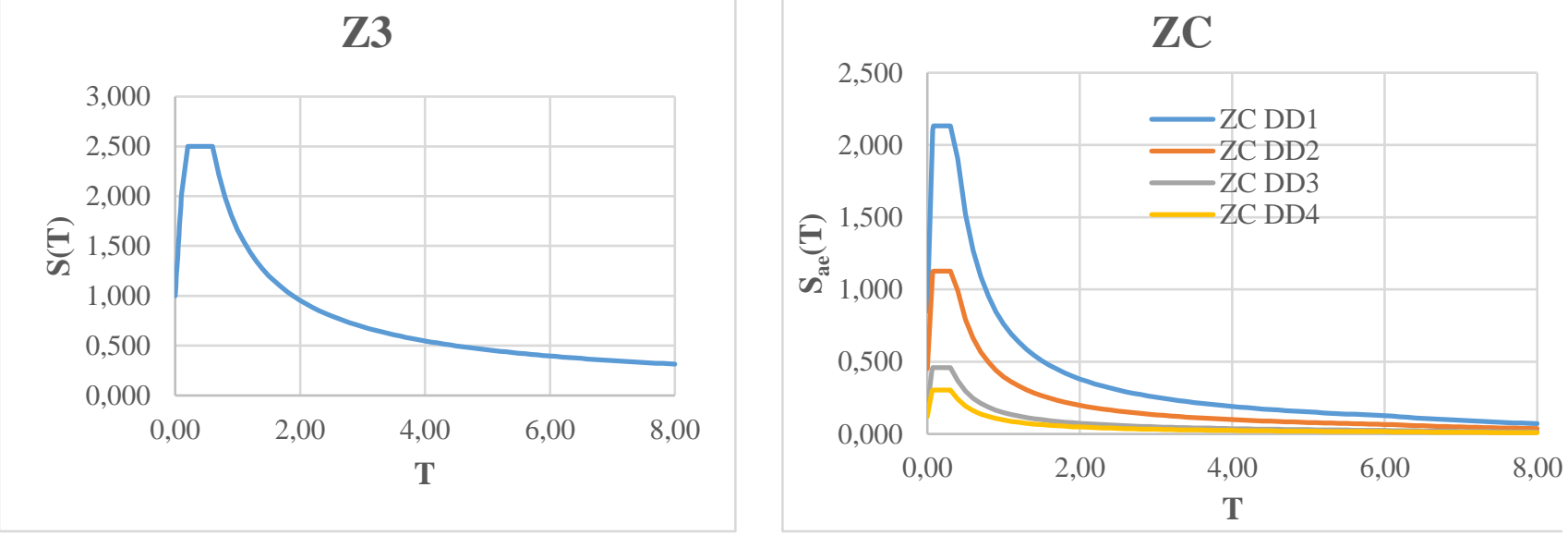

Şekil 13. Elazığ ili Z3- ZC ivme spektrumları
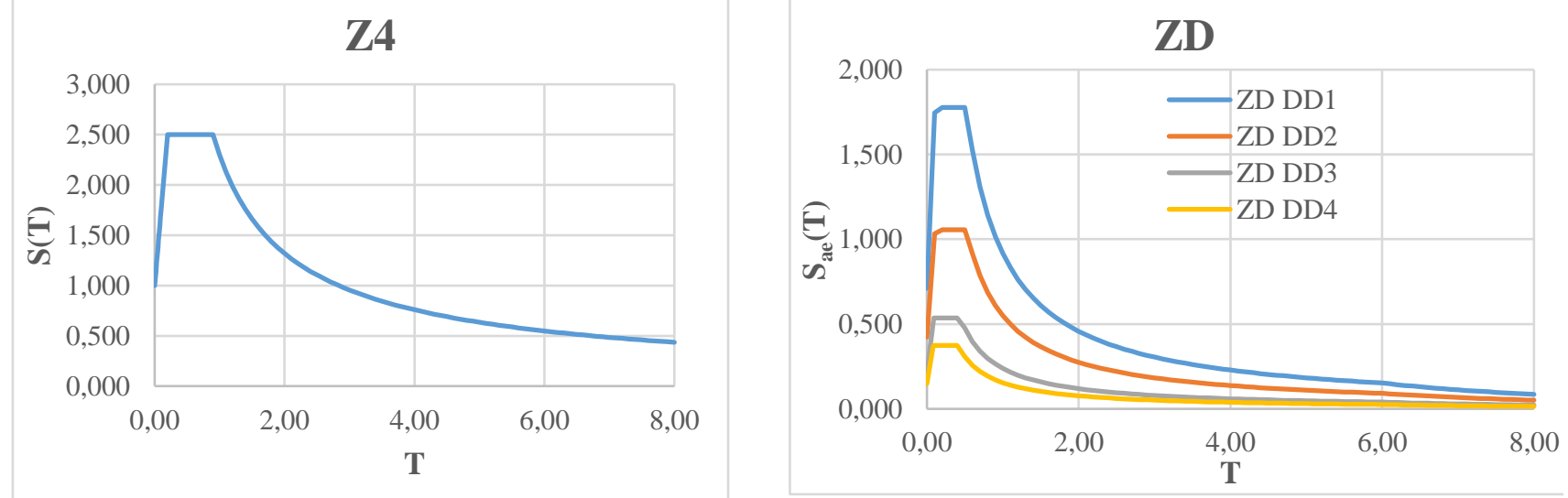

Şekil 14. Elazığ ili Z4- ZD ivme spektrumları 

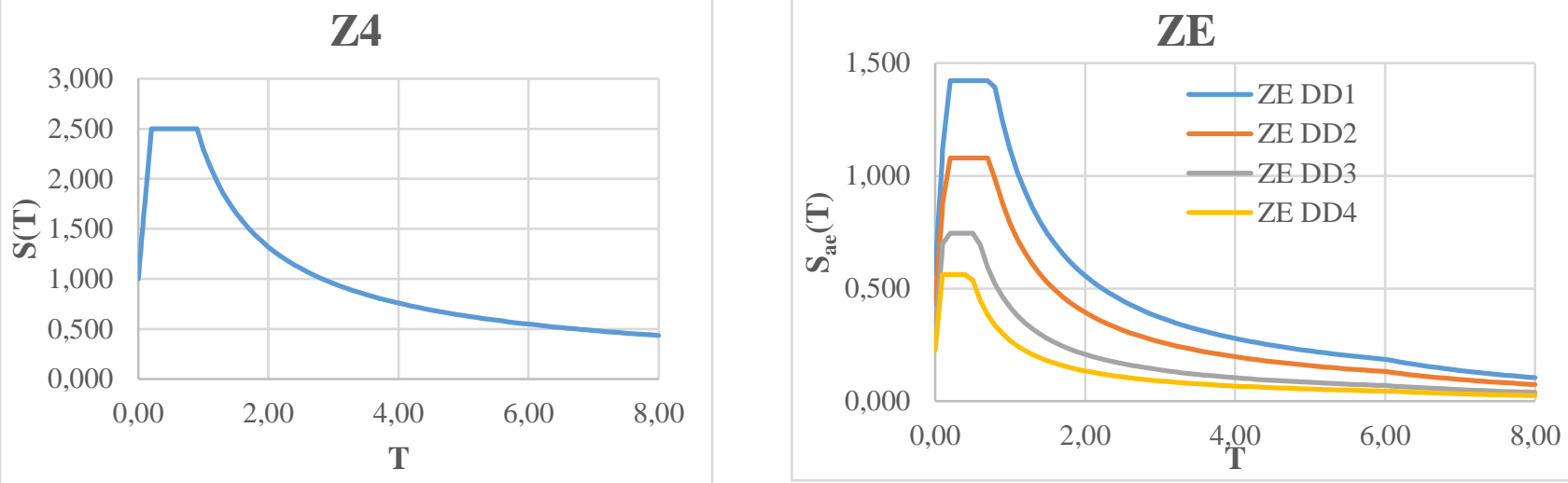

Şekil 15. Elazlğ ili Z4- ZE ivme spektrumları

Yukarıdaki șekillerde görüldüğü üzere 2007 DBYBHY'deki ivme spektrumları tek bir spektrum eğrisi ile ifade edilirken 2018 deprem yönetmeliğinde yönetmelikte tanımlanan deprem yer hareket düzeyleri aynı zemin sınıfında 4 farklı spektrum eğrisi ile ifade edilmektedir. Bu durum 2018 TBDY'de spektrum eğrilerinin deprem yer hareket düzeylerine göre değiştiğini göstermektedir. Her iki bölge için, 2007 DBYBHY'de elastik ivme spektrumundaki köşe periyotlarının ivme değerleri sabit 2.5 değerinde iken, 2018 TBDY'de bu değer koordinata dayalı S1 ve SS parametrelerinin etkisiyle farklı zemin sınıfları ve farklı deprem yer hareket düzeyleri için değişiklik göstermektedir. 2018 TBDY'de farklı deprem yer hareket düzeylerine göre en yüksek ivme değeri DD-1'de görülmekte iken en düşük ivme değerleri DD-4'te elde edilmiştir. 2007 DBYBHY'de deprem tehlikesi tek parametre yani etkin yer ivme katsayıs1 $\left(\mathrm{A}_{0}\right)$ ile ifade edilmektedir. 2018 TBDY'de ise deprem tehlikesi $S_{S}$ ve $S_{1}$ parametreleri ile tanımlanmaktadır. 2007 DBYBHY'de zemin koşulları TA ve TB'yi etkilese dahi ivme spektrumunun yalnızca azalan bölgesi yerel zemin koșullarından etkilenmektedir. Ama 2018 TBDY'de TA ve TB'nin yerel zemin koşullarından etkilenmesinin yanı sira ivme spektrumunun ivme, hız, deplasman olmak üzere 3 bölgesi de yerel zemin koșullarından etkilenmektedir. $\mathrm{Bu}$ etki Türkiye deprem tehlike haritalarından çalışma bölgesi için alınan parametrelerinden zemin özelliklerini ifade eden $\mathrm{S}_{1}$ parametresi sayesinde gerçekleşmektedir.

2007 DBYBHY'de spektrumun azalan bölgesindeki spektral ivme $\mathrm{T}^{0.8}$ ile değişirken, 2018 TBDY'de T'nin tersi ile değişmektedir. Böylelikle uzun periyotlarda spektral ivme göreli olarak azalmaktadır. 2018 TBDY'deki ivme spektrumunda $T_{L}=6$ sn'den daha uzun periyotlarda sabit spektral yer değiştirme bölgesine geçilmekte ve bu bölgede ivme $\mathrm{T}^{2}$ 'nin tersi ile değişmektedir [14]. Bu bilgiler 1şı ğında yukarıdaki grafikler incelendiğinde iki farklı bölgede bulunan Bingöl ve Elazığ illerinin spektrumlarının 2018 TBDY'ne göre farklı olduğu görülmektedir.

Tablo 2. Bingöl ve Elazı̆̆ ili için DD-2'ye göre kösse periyotlarının ( $T_{A}$ ve $\left.T_{B}\right)$ karşılaştırılması

\begin{tabular}{|c|c|c|c|c|c|c|c|c|c|c|c|c|c|c|c|c|c|c|}
\hline \multirow{3}{*}{ DD-2 } & \multicolumn{8}{|c|}{2007 DBYBHY } & \multicolumn{10}{|c|}{2018 TBDY } \\
\hline & \multicolumn{2}{|c|}{$\mathrm{Z} 1$} & \multicolumn{2}{|c|}{$\mathrm{Z} 2$} & \multicolumn{2}{|c|}{$\mathrm{Z3}$} & \multicolumn{2}{|c|}{$\mathrm{Z} 4$} & \multicolumn{2}{|c|}{$\mathrm{ZA}$} & \multicolumn{2}{|c|}{ ZB } & \multicolumn{2}{|c|}{$\mathrm{ZC}$} & \multicolumn{2}{|c|}{$\mathrm{ZD}$} & \multicolumn{2}{|c|}{$\mathrm{ZE}$} \\
\hline & $\mathrm{T}_{\mathrm{A}}$ & $\mathrm{T}_{\mathrm{B}}$ & $\mathrm{T}_{\mathrm{A}}$ & $\mathrm{T}_{\mathrm{B}}$ & $\mathrm{T}_{\mathrm{A}}$ & $\mathrm{T}_{\mathrm{B}}$ & $\mathrm{T}_{\mathrm{A}}$ & $\mathrm{T}_{\mathrm{B}}$ & $\mathrm{T}_{\mathrm{A}}$ & $\mathrm{T}_{\mathrm{B}}$ & $\mathrm{T}_{\mathrm{A}}$ & $\mathrm{T}_{\mathrm{B}}$ & $\mathrm{T}_{\mathrm{A}}$ & $\mathrm{T}_{\mathrm{B}}$ & $\mathrm{T}_{\mathrm{A}}$ & $\mathrm{T}_{\mathrm{B}}$ & $\mathrm{T}_{\mathrm{A}}$ & $\mathrm{T}_{\mathrm{B}}$ \\
\hline BİNGÖL & & & & & & & & & 0.056 & 0.282 & 0.050 & 0.251 & 0.070 & 0.352 & 0.104 & 0.520 & 0.146 & 0.730 \\
\hline & 0.10 & 0.30 & 0.15 & 0.40 & 0.15 & 0.60 & 0.15 & 0.90 & & & & & & & & & & \\
\hline ELAZIĞ & & & & & & & & & 0.052 & 0.262 & 0.046 & 0.233 & 0.065 & 0.327 & 0.098 & 0.492 & 0.154 & 0.772 \\
\hline
\end{tabular}




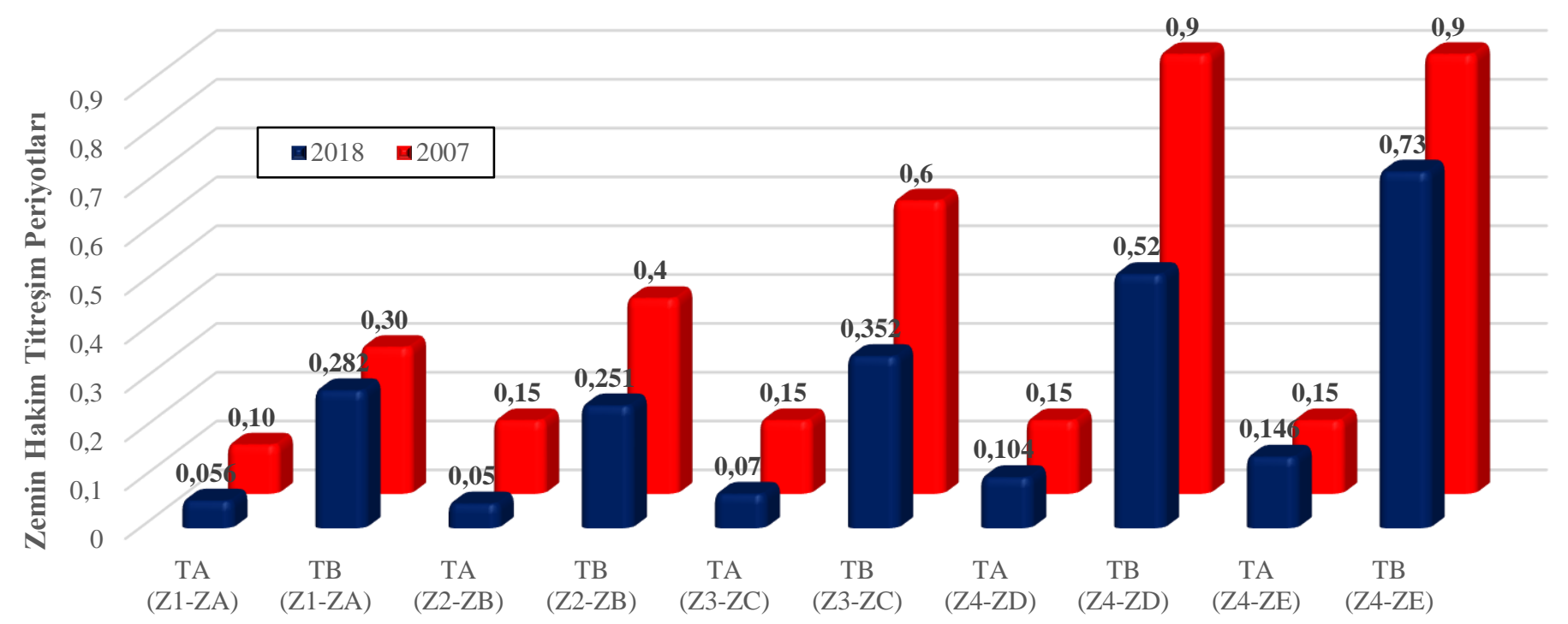

Şekil 6. Bingöl ili için DD-2'ye göre köşe periyotlarının $\left(T_{A}\right.$ ve $\left.T_{B}\right)$ değişimi

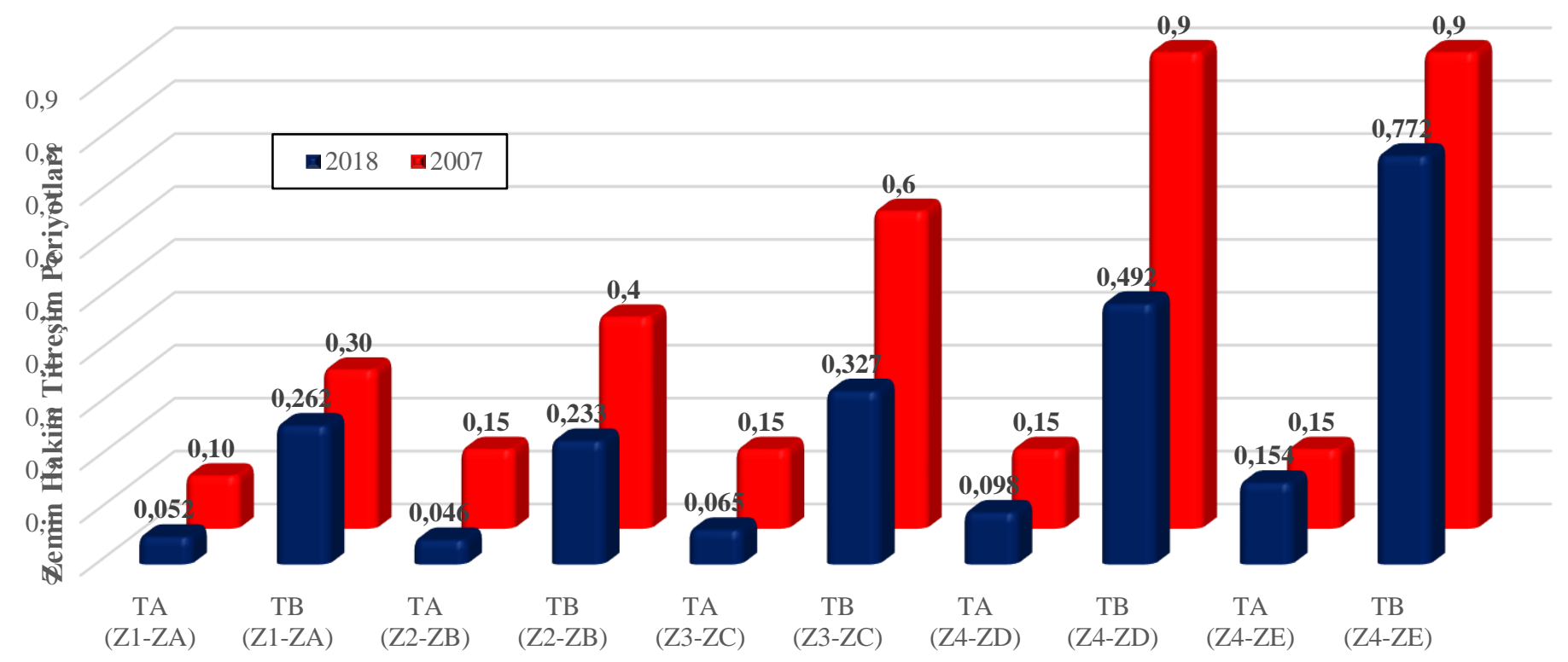

Şekil 7. Elazı̆̆ ili için DD-2'ye göre köşe periyotlarının ( $T_{A}$ ve $\left.T_{B}\right)$ değiş̧imi 
Tablo 2'de Bingöl ve Elazığ ili için DD-2'ye göre köşe periyotları verilmiştir. Köşe periyotlarının (TA ve TB) değişimi Bingöl ve Elazığ için sırasıyla Şekil 16 ve Şekil 17'de gösterilmiştir. Her iki grafikten de görüldüğü üzere, 2007 DBYBHY'ne göre Bingöl ve Elazığ ili ivme spektrumlarının köşe periyotları aynı değerleri almaktadır. 2018 TBDY'ne göre ise Bingöl ve Elazığ ilinin benzer zemin koşullarında köşe periyotları
SDS ve SD1 parametrelerine bağl1 olduğu için farklılık göstermektedir. Koçer vd. [12] Türkiye'deki farklı bölgelerin ivme spektrumlarını inceledikleri çalışmada, 2007 deprem yönetmeliğindeki köşe periyotları bölgesel olarak değişmediği, 2018 TBDY'deki köşe periyotlarının ise bölgesel farklılıklar gösterdiği belirtilmiştir. 2007 ve 2018 deprem yönetmeliklerinde verilen yerel zemin sinıfları sirasıyla Tablo 3 ve Tablo 4 'te verilmiştir.

Tablo 3. 2007 DBYBHY yerel zemin siniflarl[6]

\begin{tabular}{|c|c|c|c|c|c|}
\hline $\begin{array}{l}\text { Zemin } \\
\text { Grubu }\end{array}$ & Zemin Grubu Tanımı & $\begin{array}{l}\text { Stand. } \\
\text { Penetr. } \\
(\mathrm{N} / 30)\end{array}$ & $\begin{array}{l}\text { Relatif } \\
\text { Sik1lik } \\
(\%)\end{array}$ & $\begin{array}{l}\text { Serbest } \\
\text { Basınç } \\
\text { Direnci } \\
(\mathrm{kPa}) \\
\end{array}$ & $\begin{array}{c}\text { Kayma } \\
\text { Dalgası } \\
\text { Hizı }(\mathrm{m} / \mathrm{s})\end{array}$ \\
\hline (A) & $\begin{array}{l}\text { 1. Masif volkanik kayaçlar ve } \\
\text { ayrışmamış sağlam } \\
\text { metamorfik kayaçlar, sert } \\
\text { çimentolu tortul kayaçlar... }\end{array}$ & - & - & $>1000$ & $>1000$ \\
\hline & 2. Çok sık1 kum, çakı1.... & $>50$ & $85-100$ & - & $>700$ \\
\hline & 3. Sert kil ve siltli kil.... & $>32$ & - & $>400$ & $>700$ \\
\hline (B) & $\begin{array}{l}\text { 1. Tüf ve aglomera gibi } \\
\text { gevşek volkanik kayaçlar, } \\
\text { süreksizlik düzlemleri bulunan } \\
\text { ayrışmış çimentolu tortul } \\
\text { kayaçlar.... }\end{array}$ & - & - & $500-1000$ & $700-1000$ \\
\hline & 2. S1k1 kum, çakı1.... & $30-50$ & $65-85$ & - & $400-700$ \\
\hline & 3. Çok katı kil ve siltli kil.... & $16-32$ & - & $200-400$ & $300-700$ \\
\hline ( C ) & $\begin{array}{l}\text { 1. Yumuşak süreksizlik } \\
\text { düzlemleri bulunan çok } \\
\text { ayrışmış metamorfik kayaçlar } \\
\text { ve çimentolu tortul kayaçlar... } \\
\text { 2. Orta sıkı kum, çakıl... } \\
\text { 3. Katı kil ve siltli kil... }\end{array}$ & $\begin{array}{c}- \\
10-30 \\
8-16\end{array}$ & $\begin{array}{c}- \\
35-65 \\
-\end{array}$ & $\begin{array}{c}<500 \\
- \\
100-200\end{array}$ & $\begin{array}{l}400-700 \\
200-400 \\
200-300\end{array}$ \\
\hline (D) & $\begin{array}{l}\text { 1. Yeraltı su seviyesinin } \\
\text { yüksek olduğu yumuşak, kalın } \\
\text { alüvyon tabakaları... } \\
\text { 2. Gevşek kum... } \\
\text { 3. Yumuşak kil, siltli kil... }\end{array}$ & $\begin{array}{l}- \\
<10 \\
<8\end{array}$ & $\begin{array}{l}- \\
<35 \\
-\end{array}$ & $\begin{array}{c}- \\
- \\
<100\end{array}$ & $\begin{array}{l}<200 \\
<200 \\
<200\end{array}$ \\
\hline
\end{tabular}


Tablo 4. 2018 TBDY yerel zemin siniflart[6]

\begin{tabular}{|c|c|c|c|c|}
\hline \multirow{2}{*}{$\begin{array}{l}\text { Yerel } \\
\text { Zemin } \\
\text { Sinifi }\end{array}$} & \multirow[b]{2}{*}{ Zemin Cinsi } & \multicolumn{3}{|c|}{ Üst 30 metrede ortalama } \\
\hline & & $\begin{array}{l}\left(\mathrm{V}_{\mathrm{s}}\right)_{30} \\
{[\mathrm{~m} / \mathrm{s}]}\end{array}$ & $\begin{array}{c}\left(\mathrm{N}_{60}\right)_{30} \\
{[\text { darbe/30cm] }}\end{array}$ & $\begin{array}{l}\left(\mathrm{c}_{\mathrm{u}}\right)_{30} \\
{[\mathrm{kPa}]}\end{array}$ \\
\hline $\mathrm{ZA}$ & Sağlam sert kayalar & $>1500$ & - & - \\
\hline $\mathrm{ZB}$ & Az ayrışmış orta sağlam kayalar & $760-1500$ & - & - \\
\hline $\mathrm{ZC}$ & $\begin{array}{l}\text { Çok sıkı kum, çakıl ve sert kil tabakaları } \\
\text { veya ayrışmış çok çatlaklı zayıf kayalar }\end{array}$ & $360-760$ & $>50$ & $>250$ \\
\hline $\mathrm{ZD}$ & $\begin{array}{l}\text { Orta sıkı-sıkı kum, çakıl veya çok katı kil } \\
\text { tabakaları }\end{array}$ & $180-360$ & $15-50$ & $70-250$ \\
\hline $\mathrm{ZE}$ & $\begin{array}{l}\text { Gevşek Kum, çakıl veya yumuşak-katı } \\
\text { kil tabakaları veya PI }>20 \text { ve }>\% 40 \\
\text { koşullarını sağlayan toplamda } 3 \text { metreden } \\
\text { daha kalın yumuşak kil tabakası }(\mathrm{cu}<25 \\
\mathrm{kPa} \text { ) içeren profiller }\end{array}$ & $<180$ & $<15$ & $<70$ \\
\hline & \multicolumn{4}{|c|}{ Sahaya özel araştırma ve değerlendirme gerektiren zeminler: } \\
\hline ZF & \multicolumn{4}{|c|}{$\begin{array}{l}\text { 1)Deprem etkisi altında çökme ve potansiyel göçme riskine sahip } \\
\text { zeminler(sıvılaşabilir zeminler, yüksek derecede hassas killer, vb.) }\end{array}$} \\
\hline & \multicolumn{4}{|c|}{$\begin{array}{l}\text { 2)Toplam kalınlığı } 3 \text { metreden fazla turba ve/veya organik içeriği yüksek killer, } \\
\text { 3)Toplam kalınlığı } 8 \text { metreden fazla olan yüksek plastisiteli (PI>50) killer } \\
\text { 4)Çok kalın (>35 m) yumuşak veya orta katı killer }\end{array}$} \\
\hline
\end{tabular}

Tablo 5. 2018 TBDY kusa periyot bölgesi için yerel zemin etki katsayıları[6]

\begin{tabular}{ccccccc}
\hline $\begin{array}{c}\text { Yerel } \\
\text { Zemin }\end{array}$ & \multicolumn{6}{c}{ Kisa periyot bölgesi için Yerel Zemin Etki Katsayısı Fs } \\
Sınıfı & Ss $\leq 0.25$ & Ss $=0.50$ & Ss $=0.75$ & Ss $=1.00$ & Ss $=1.25$ & Ss $\geq 1.50$ \\
\hline ZA & 0.8 & 0.8 & 0.8 & 0.8 & 0.8 & 0.8 \\
ZB & 0.9 & 0.9 & 0.9 & 0.9 & 0.9 & 0.9 \\
ZC & 1.3 & 1.3 & 1.2 & 1.2 & 1.2 & 1.2 \\
ZD & 1.6 & 1.4 & 1.2 & 1.1 & 1.0 & 1.0 \\
ZE & 2.4 & 1.7 & 1.3 & 1.1 & 0.9 & 0.8 \\
ZF & \multicolumn{7}{c}{ Sahaya özel zemin davranış analizi yapilacaktır. } \\
\hline \multicolumn{7}{c}{}
\end{tabular}


Tablo 6. 2018 TBDY 1.0 saniye periyot için yerel zemin etki katsayıları [6]

\begin{tabular}{ccccccc}
\hline Yerel & \multicolumn{5}{c}{1.0 saniye periyot için Yerel Zemin Etki Katsayısı $\mathrm{F}_{1}$} \\
$\begin{array}{c}\text { Zemin } \\
\text { Sınıfi }\end{array}$ & $\mathrm{S}_{1} \leq 0.10$ & $\mathrm{~S}_{1}=0.20$ & $\mathrm{~S}_{1}=0.30$ & $\mathrm{~S}_{1}=0.40$ & $\mathrm{~S}_{1}=0.50$ & $\mathrm{~S}_{1} \geq 0.60$ \\
\hline $\mathrm{ZA}$ & 0.8 & 0.8 & 0.8 & 0.8 & 0.8 & 0.8 \\
$\mathrm{ZB}$ & 0.8 & 0.8 & 0.8 & 0.8 & 0.8 & 0.8 \\
$\mathrm{ZC}$ & 1.5 & 1.5 & 1.5 & 1.5 & 1.5 & 1.4 \\
$\mathrm{ZD}$ & 2.4 & 2.2 & 2.0 & 1.9 & 1.8 & 1.7 \\
$\mathrm{ZE}$ & 4.2 & 3.3 & 2.8 & 2.4 & 2.2 & 2.0 \\
$\mathrm{ZF}$ & \multicolumn{7}{c}{ Sahaya özel zemin davranış analizi yapilacaktır. } \\
\hline \multicolumn{7}{c}{}
\end{tabular}

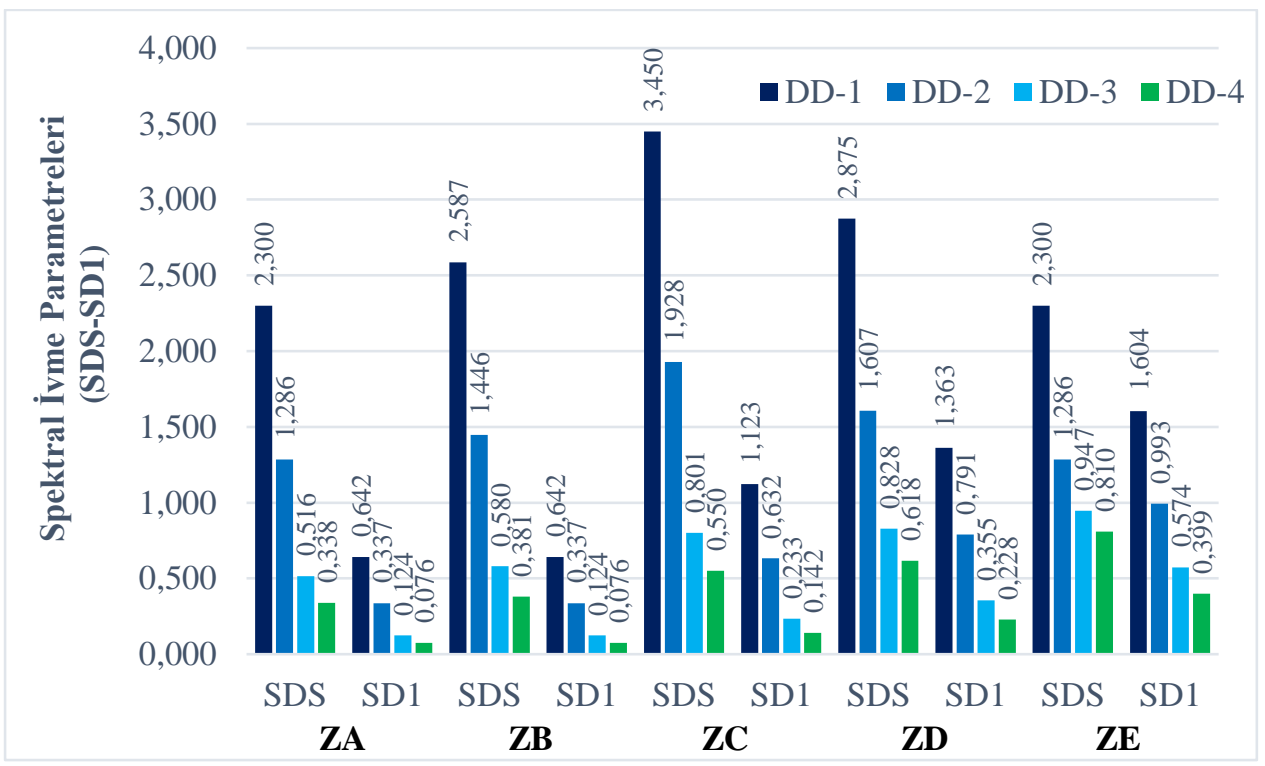

Şekil 8. 2018 TBDY Bingöl ili için spektral ivme parametrelerinin zemin sınıfi ve deprem tasarım sinıfi için değişimi 


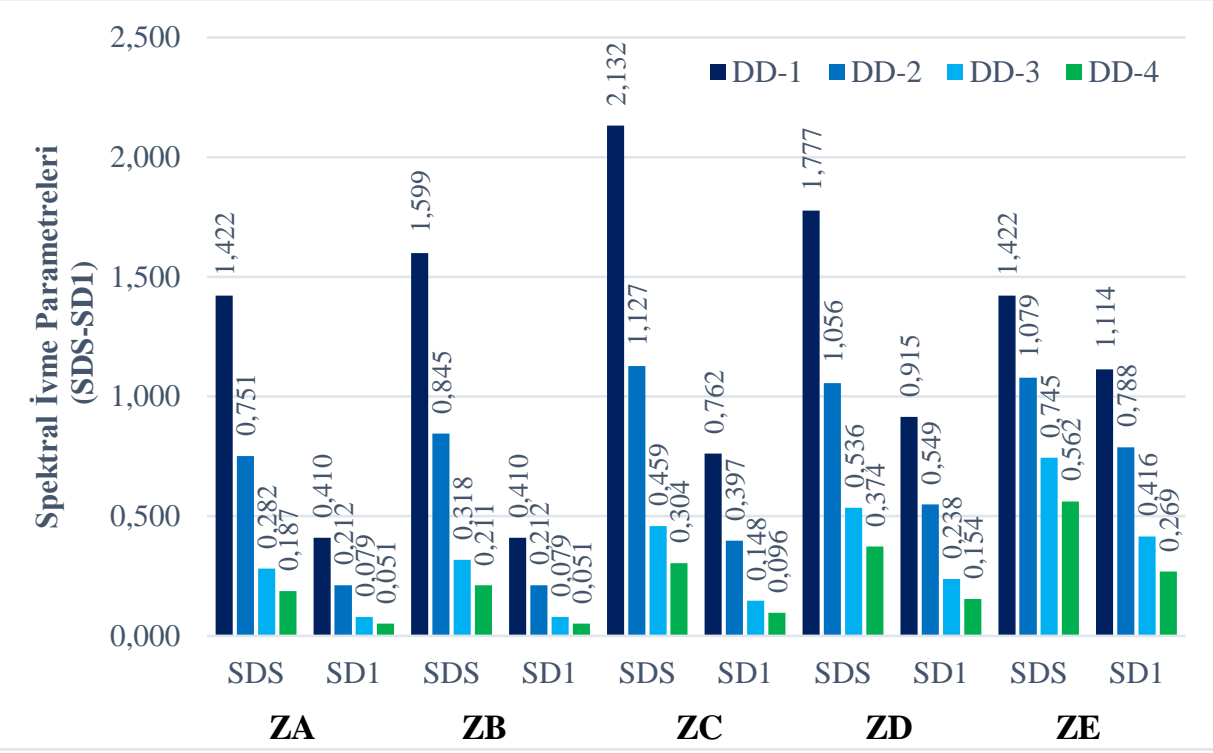

Şekil 9. 2018 TBDY Elazığ ili için spektral ivme parametrelerinin zemin sınıfi ve deprem tasarım sinıfi için değişimi

verilen $\mathrm{F}_{1}$ yerel zemin etki katsayıları (Tablo

2018 TBDY'de ivme spektrumlarının oluşturulması için kullanılan koordinata dayalı parametreler olan $S_{\mathrm{DS}}$ ve $\mathrm{S}_{\mathrm{D} 1}$ değerleri Tablo 5 ve Tablo 6'teki yerel zemin etki katsayılarına göre değişiklik göstermektedir. Şekil 18 ve Şekil 19'da sırasıyla Bingöl ve Elazı̆̆ illeri için bu değerlerin değişimi verilmiştir. Şekil 18 'de Bingöl ili için verilen $S_{D S}$ ve $S_{D 1}$ değerlerinin değişimi incelendiğinde; ZA zemin sınıfından ZC zemin sinıfına doğru $\mathrm{S}_{\mathrm{DS}}$ değerlerinde bir artış meydana gelmiş iken ZC zemin sinıfından ZE zemin sinıfına doğru gidildikçe $\mathrm{S}_{\mathrm{DS}}$ değerleri azalmıştır. $\mathrm{Bu}$ sonuç Şekil 19'daki Elazığ ili için de geçerlidir. Fakat aynı değişim $\mathrm{S}_{\mathrm{D} 1}$ değerleri için geçerli değildir. Şekil 18 ve Şekil 19 incelendiğinde çalışma kapsamında ele alınan her iki bölge için $\mathrm{S}_{\mathrm{D} 1}$ değerleri $\mathrm{ZA}$ zemin sınıfından $\mathrm{ZE}$ zemin sınıfına doğru bir artış göstermektedir. 2018 deprem yönetmeliğinde verilen yerel zemin etki katsayıları tabloları incelendiğinde, kısa periyot ivme katsayıları için verilen $F_{S}$ yerel zemin etki katsayıları (Tablo 3), Ss değerinin 1'den büyük olduğu durumlarda, ZA zemin sinıfindan ZC zemin sinıfina kadar bir artış, ZC zemin sınıfindan ZE zemin sınıfına kadar bir azalma göstermesidir. Fs yerel zemin etki katsayılarındaki bu değişimin temel nedeni $S_{S}$ değerinin 1'den küçük ya da büyük olma durumudur. 2018 TBDY'de verilen yerel zemin etki katsayıları tabloları incelendiğinde, uzun $(1.0 \mathrm{sn})$ periyot ivme katsayıları için
4), $\mathrm{S}_{1}$ değerinin $\mathrm{ZA}$ zemin sinıfindan $\mathrm{ZE}$ zemin sınıfına kadar bir artıs göstermektedir. Şekil 18 ve Şekil 19 incelendiğinde ele alınan bölgelerdeki zemin durumu koordinata dayalı ivme parametrelerinin değişimini doğrudan etkilemektedir.

2018 TBDY'de verilen koordinata dayalı deprem parametrelerinden $\mathrm{S}_{\mathrm{S}}$ değeri ilgili bölgenin deprem etkisini, $\mathrm{S}_{1}$ değeri ele alınan bölgenin zemin özelliklerini ifade etmektedir. 2018 TBDY ile birlikte verilen deprem tehlike haritaları zemin ortamının en üst 30 m'sindeki ortalama kayma dalgası hızının $760 \mathrm{~m} / \mathrm{sn}$ olduğu zemin durumu için oluşturulmuştur. $\mathrm{Bu}$ değer deprem yönetmeliğinde tanımlanan zemin sinıflandırmasında ZB ile ZC arasında bir değere karşılık gelmektedir [14]. Bu nedenle 2018 deprem yönetmeliğinde verilen yerel zemin etki katsayısı tabloları (Tablo 3, Tablo 4) ZA ve ZB yerel zemin sınıfları için bir azaltma $Z C, Z D$ ve $Z E$ zemin sınıfları için ise bir büyütme öngörmektedir. Sadece, $\mathrm{S}_{\mathrm{S}}$ ivme parametresi için verilen $F_{S}$ yerel zemin etki katsayısı değerleri $S_{S}$ 'in 1 ve 1'den büyük olduğu durumlarda ZC zemin sinıfindan ZE zemin sinıfına doğru yapılması gereken büyütme oranında bir azalma göstermektedir. Bunun nedeni ivme değerlerinin büyük olduğu durumlarda ek bir zemin büyütmesinin önüne geçmektir. 


\section{Sonuçlar}

Bu çalışmada 2007 ve 2018 deprem yönetmeliklerine göre Bingöl ve Elazığ ilinin ivme spektrumları arasındaki farklar incelenmiş ve aşağıdaki sonuçlar elde edilmişstir.

- 2007 deprem yönetmeliğinde tek deprem yer hareket düzeyine göre (50 y1lda aşılma olasilığ $1 \% 10$ olan standart deprem yer hareketi) ivme spektrumu oluşturulurken, 2018 deprem yönetmeliğinde DD-1, DD-2, DD-3 ve DD-4 olmak üzere 4 farklı deprem yer hareket düzeyine göre ivme spektrumları elde edilmektedir.

- 2007 deprem yönetmeliğinde deprem bölgesi kavramı bulunurken 2018 deprem yönetmeliğinde koordinata dayalı deprem parametreleri elde etmeye olanak sağlayan deprem tehlike haritaları getirilmiştir.

- 2007 deprem yönetmeliğinde ivme parametresi olarak $A_{0}$, etkin yer ivme katsayısı yerel zemin sınıflarına göre sabit katsayılar olarak verilmiş iken, 2018 deprem yönetmeliğinde ivme katsayıları koordinata dayalı olarak deprem tehlike haritalarından elde edilmektedir.

- 2007 deprem yönetmeliğinde köşe periyotları sabit değerler alırken, 2018 deprem yönetmeliğine göre $S_{D S}$ ve $S_{D 1}$ parametrelerine bağlı olarak bölgesel değişmektedir.

- $\quad$ SS'in 1'den küçük olduğu değerler için verilen yerel zemin etki katsayılarına bağlı olarak $S_{D S}$ değerleri sürekli bir artış gösterirken, 1 ve 1 'den büyük değerleri için yerel zemin etki katsayılarına bağlı olarak $S_{D S}$ değerinin ZC yerel zemin sınıfından ZE zemin sınıfına doğru artış miktarında bir azalma meydana gelmiştir.

- $S_{1}$ parametresinin bütün değerlerinde zemin sınıflarında iyi zeminden kötü zemine doğru $\mathrm{S}_{\mathrm{D} 1}$ parametresi sürekli bir artış göstermektedir.

- Deprem tasarım esaslarında koordinata bağlı çalışan 2018 Türk deprem yönetmeliğinde ivme spektrumları kullanılacağı konumuna göre değişiklik göstermektedir. 2007 Türk deprem yönetmeliğinde ise ivme spektrumları konuma göre değişiklik göstermemektedir. Bu nedenle deprem tasarım esasları açısından, 2018 Türk deprem yönetmeliğindeki ivme değerlerinin, 2007 Türk deprem yönetmeliğindeki sabit ivme değerlerine kiyasla ekonomik ve emniyetli bir durum gösterdiği söylenebilir.

- Bu çalışma, ülkemizde uzun yıllardan beri kullanımda olan Deprem Binalarında Yapılacak Binalar Hakkında Yönetmelik 2007'den Türkiye Bina Deprem Yönetmeliği 2018'e geçildikten sonra yapılan çalışmaların, günümüz inşaat teknolojisine uyumlu, güncel hesap yaklaşımlarıyla yapıların davranışlarını daha doğru yansitabildiğini göstermektedir. Çalışmanın literatürde yer alan mevcut çalışmalara kıyasla yönetmeliklerdeki ivme spektrum kavramını daha detaylı olarak açıklamakta ve örneklerle karşılaştırmaktadır. Ayrıca, çalışma ile birlikte 2018 Türk deprem yönetmeliğine göre deprem hesapları yapilırken, hesaplarda büyük öneme sahip ivme spektrumu kavramı daha kolay anlaşılacaktır.

\section{Kaynaklar}

[1]Celep, Z.,Kumbasar, N., (2005). Betonarme Yapılar, Beta Basım Yayın.

[2]Rangin, C.,Bader, A.G., Pascal, G., Ecevitoğlu, B., Görür, N., (2002). Deep structure of the Mid Black Sea High (offshore Turkey) imaged by multi-channel seismic survey (BLACKSIS cruise), Marin Geology.

[3]K.R. ve D.A. Enstitüsü, (2019). Türkiye'de Meydana Gelen Büyük Depremler, Kandilli Rasath. koeri.boun.edu.tr.

[4]Alyamaç, K.E., Erdoğan, A.S., (2005). Geçmişten Günümüze Afet Yönetmelikleri ve Uygulamada Karşılaşılan Tasarım Hataları, Deprem Sempozyuти. 707-715.

[5]Nemutlu, Ö.F., Sari, A., (2019). 2018 Yeni Türk Deprem Yönetmeliği İle Amerikan Deprem Yönetmeliklerinin Deprem Hesapları Açısından Karşılaştırılması, 5th International Conference Earthquake Engineering and Seismology., Ankara,Türkiye. 
[6]Afet ve Acil Durum Başkanlığg,(2018). Türkiye Bina Deprem Yönetmeliği2018(TBDY-2018).

[7]Tunç, G., Tanfener, T., (2016). 2007 ve 2016 Türkiye Bina Deprem Yönetmeliklerinin Örneklerle Mukayesesi.

[8]Nemutlu, Ö.F., Sar1, A., (2018). Comparison Of Turkish Earthquake Code in 2007 With Turkish Earthquake Code in 2018, International Engineering and Natural Science Conference, Diyarbakır, pp. 14-25.

[9]Afet ve Acil Durum Yönetimi Başkanlığı, (2018). http//:tdth.afad.gov.tr.

[10]Afet ve Acil Durum Başkanlığı, Deprem Bölgelerinde Yapılacak Binalar Hakkında Yönetmelik-2007(DBYBHY-2007), (2007).

[11]Öztürk, D., Bozdoğan, K.B., (2013). Elastik Ötesi Spektrum Kullanılarak Yapıların Doğrusal Olmayan Analizi, SDU International Technol. Sci. 5, 49-55.

[12]Koçer, M., Nakipoğlu, A., Öztürk, B., Alhagri, M.G., Arslan, M.H., (2018). Deprem Kuvvetine Esas Spektral İvme Değerlerinin Tbdy 2018 Ve Tdy 2007'ye Göre Karşılaştırılması, Selçuk-Teknik Dergisi. 17, 43-58.

[13]Fan, X., Wang, K., Xiao, S., (2018). Large-scale parallel computation for earthquake response spectrum analysis, Engineering Computations 35, 800-817.

[14]Aydınoğlu, N.M., Celep, Z., Özer, E., Özaydın, K., (2018). Türkiye Bina Deprem Yönetmeliği Eğitim Sunumları, TMMOB Inşaat Mühendisleri Odası.

[15]Housner, G.W., (1952). Spectrum Intensities of Strong-Motion Earthquakes, Symp. Earthq. Blast Effect Structure.

[16]Seed, H.B., Idriss, I., M., (1982). Ground Motion and Soil Liquefaction During Earthquakes.
[17]Newmark, N., Hall, W., (1982). Earthquake Spectra and Design, EERI Monogr.

[18]International Building Code 2018(IBC2018), (2018). International Code Council.

[19]Minimum Design Loads and Associated Criteria for Buildings and Other Structures(ASCE 7-16), (2017). American Society of Civil Engineers.

[20]Fahjan, Y., Türk Bina Deprem Yönetmeliği (TBDY, 2017), (2017). Tabanlı Tasarım Spektrumları, IMO İzmir Şubesi, İzmir

[21]Chopra, A., K., (2007). Elastic response spectrum: A historical note, Earthquake Engineering and Structural Dynamics. 36, 312.

[22]Song, J., Chu, Y., Liang, Z., Lee, G., C., (2007). Estimation of peak relative velocity and peak absolute acceleration of linear SDOF systems, Earthquake Engineering and Engineering Vibration. 6(1), 1-10.

[23]Uçar, T., Merter, O., (2012). Binaların deprem hesabında kullanılan doğrusal elastik hesap yöntemleriyle ilgili bir irdeleme, Ordu Üniv. Bil. Tek. Derg. 2, 15-31.

[24]Kale, Ö., Akkar, S., (2015). Tasarım spektrumu köşe periyotları ve zemin amplifikasyon katsayılarının olasılıksal sismik tehlike analizleri ile belirlenmesi, 3. Türkiye Deprem Mühendisliği ve Sismoloji Konferansl, DEÜ- İzmir.

[25]Yon, B., Calayir, Y., (2015). The soil effect on the seismic behaviour of reinforced concrete buildings, Earthquake and structures 8, 133-152.

[26]Yon, B., Oncu, M.E., Calayir, Y., (2015). Effects of seismic zones and local soil conditions on response of RC buildings, Gradevinar 67, 585-596. 